\title{
Ex Vivo Adenovirus-Mediated Gene Transfer to Corneal Graft Endothelial Cells in Mice
}

\section{Citation}

Qian, Ying, Fee-Lai Leong, Andrius Kazlauskas, and M. Reza Dana. 2004. “Ex Vivo AdenovirusMediated Gene Transfer to Corneal Graft Endothelial Cells in Mice." Investigative Opthalmology \& Visual Science 45 (7) (July 1): 2187. doi:10.1167/iovs.03-0901.

\section{Published Version}

10.1167/iovs.03-0901

\section{Permanent link}

http://nrs.harvard.edu/urn-3:HUL.InstRepos:34388128

\section{Terms of Use}

This article was downloaded from Harvard University's DASH repository, and is made available under the terms and conditions applicable to Other Posted Material, as set forth at http:// nrs.harvard.edu/urn-3:HUL.InstRepos:dash.current.terms-of-use\#LAA

\section{Share Your Story}

The Harvard community has made this article openly available.

Please share how this access benefits you. Submit a story.

\section{Accessibility}




\title{
Ex Vivo Adenovirus-Mediated Gene Transfer to Corneal Graft Endothelial Cells in Mice
}

\author{
Ying Qian, Fee-Lai Leong, Andrius Kazlauskas, and M. Reza Dana
}

Purpose. Genetic modulation of donor tissue before corneal transplantation may have the potential to modulate alloimmunity and/or to prevent corneal endothelial cell death. This study was conducted to optimize adenovirus-mediated gene transfer to donor corneal endothelium and to delineate the kinetics of marker gene expression in syngeneic and allogeneic corneal grafts.

Methods. BALB/c mouse corneas were incubated with replication-deficient adenovirus encoding green fluorescent protein (GFP) or empty vector ex vivo at a dose of $6 \times 10^{7}$ or $6 \times 10^{6}$ PFU at temperatures of $4{ }^{\circ} \mathrm{C}$ or $37^{\circ} \mathrm{C}$. After ex vivo infection, the donor corneas were transplanted orthotopically to BALB/c or C57BL/6 recipients. After transplantation, localization of GFP in the grafts was determined in cryosections of enucleated eyes, and GFP expression in the grafts was visualized in vivo by using epifluorescence microscopy over 12 weeks. All grafts were evaluated clinically by slit lamp biomicroscopy.

REsults. GFP expression was found to be restricted to the corneal endothelium. In vivo expression of GFP in syngeneic corneal grafts was demonstrated for up to 12 weeks. Syngeneic grafts incubated with the vector at $4^{\circ} \mathrm{C}$ exhibited a more extensive and longer duration of expression of green fluorescence than grafts incubated at $37^{\circ} \mathrm{C}$. Moreover, the syngeneic grafts infected at $4^{\circ} \mathrm{C}$ maintained their transparency, whereas those infected at $37^{\circ} \mathrm{C}$ displayed a high degree of opacity. Corneal allogeneic grafts infected with a low dose of the vector displayed longer GFP expression and graft survival than the allogeneic grafts infected with a high dose of the viral vector.

Conclusions. Adenoviral vector can selectively and efficiently deliver exogenous gene(s) to the endothelium of corneal grafts during hypothermic organ preservation. Gene expression is retained in vivo in corneal syngeneic grafts for longer periods than are allogeneic grafts. (Invest Ophthalmol Vis Sci. 2004;45: 2187-2193) DOI:10.1167/iovs.03-0901

Corneal transplantation, also known as penetrating kerato$\checkmark$ plasty, involves the replacement of diseased cornea by a graft of homologous tissue. It is the major treatment available to reverse the loss of sight caused by damage to the cornea, which represents the second most common cause of blindness

From The Schepens Eye Research Institute, Department of Ophthalmology, Harvard Medical School, Boston, Massachusetts.

Supported by the Roche Organ Transplantation Research Fund; Eye Bank Association of America; the U.S. Department of Defense and the Aging Eye Center, Schepens Eye Research Institute; and National Eye Institute Grant R01-12963 (MRD). AK is a Research to Prevent Blindness Olga Keith Weiss Scholar.

Submitted for publication August 19, 2003; accepted September 26, 2003

Disclosure: Y. Qian, None; F.-L. Leong, None; A. Kazlauskas, None; M.R. Dana, None

The publication costs of this article were defrayed in part by page charge payment. This article must therefore be marked "advertisement" in accordance with 18 U.S.C. $\$ 1734$ solely to indicate this fact.

Corresponding author: M. Reza Dana, Laboratory of Immunology, Schepens Eye Research Institute, Harvard Medical School, 20 Staniford Street, Boston, MA 02114; dana@vision.eri.harvard.edu. worldwide after cataract. It is estimated that well over 10 million people are corneally blind in the world. ${ }^{1}$ While corneal transplantation is the most common and arguably one of the most successful forms of solid tissue transplantation, graft failure is still not uncommon. Loss of the endothelial cell of the transplanted cornea is a major factor contributing to the failure of corneal transplants. A number of factors including allograft rejection, endothelial contact with an intraocular lens or vitreous, uncontrolled inflammation, additional ocular surgery, eye trauma, and increased intraocular pressure, have been shown to cause a rapid decline in endothelial cells, leading directly to graft failure. ${ }^{2}$ Hence, while immune rejection targeted at the endothelium is the leading cause of graft failure, endothelial cell loss probably represents a common denominator of graft edema and failure. ${ }^{3}$

The cornea is a particularly suitable candidate tissue for gene-based approaches in transplantation for several reasons: (1) Unlike some other solid organs, it can be preserved for periods of several weeks, allowing time for ex vivo genetic alteration before transplantation; (2) the transparency of the cornea allows for direct visualization of any significant consequences of gene transfer; (3) maintenance of corneal transparency is so dependent on the normal activity of corneal endothelial cells that they make for an attractive target for gene therapy strategy, as alterations in this one cell layer can have profound effects on the remainder of the tissue; (4) corneal endothelial cells are readily accessible (as they are in direct contact with the storage medium) and hence amenable to gene transfer; and finally, (5) the corneal endothelium has a distinct advantage as a target for gene therapy. Transgene expression in most organs is transient and is limited by a cellular immune responses directed against transduced cells, viral proteins, and foreign transgene proteins. ${ }^{4,5}$ In contrast, prolonged and persistent adenovirus-mediated transgene expression is observed in immune-privileged sites such as the eye and brain. ${ }^{6}$ Because the anterior chamber of the eye is an immune-privileged site, the anatomic location of the corneal endothelium makes it an optimal site for gene transfer.

We have a well-established and validated mouse model of murine corneal transplantation that faithfully reflects the experience with keratoplasty in humans. ${ }^{7,8}$ While several groups have had some success in gene transfer to the corneal endothelium of human, ${ }^{9}$ rabbit, ${ }^{10,11}$ rat, ${ }^{11}$ and sheep, ${ }^{12}$ their techniques cannot be applied directly to our mouse model of transplantation because different animal models and genes have been tested, and the gene transfer was conducted at $37^{\circ} \mathrm{C}$ in all those studies-an unacceptably high temperature for long-term storage of the donor corneal tissue in the standard storage medium in use worldwide. In addition, in all these studies, investigators examined ex vivo gene expression and none reported the kinetics of adenovirus-mediated gene transferred in the endothelium of corneal grafts in vivo.

In this study, we used an adenoviral vector encoding green fluorescent protein (GFP) to infect mouse donor corneas, and transplanted these donor corneas orthotopically to either syngeneic or allogeneic recipients. We wanted to examine the localization and kinetics of GFP expression in corneal grafts in 
vivo and the effect of such a gene transfer on the fate of the corneal grafts.

\section{MethodS}

\section{Animals}

BALB/c mice (Taconic Farm, Germantown, NY) aged 8 to 10 weeks were used as corneal recipients; $\mathrm{BALB} / \mathrm{C}$ and $\mathrm{C} 57 \mathrm{BL} / 6$ mice of the same age were used as corneal donors. Before all surgical procedures, each animal was deeply anesthetized by intraperitoneal injection of 3-4 mg of ketamine and $0.1 \mathrm{mg}$ of xylazine. All animals were treated in accordance with the ARVO Statement for the Use of Animals in Ophthalmic and Vision Research.

\section{Infection of Donor Corneas Ex Vivo}

The vector used in this study was an E1- and E3-deleted serotype 5 adenoviral vector carrying the GFP gene (ad-GFP) under the transcriptional control of the cytomegalovirus promoter that was constructed, propagated in 293 cells, purified by density gradient method, and stored at $-70^{\circ} \mathrm{C}$ until use. Both the GFP adenoviral and control (empty) vector that contained no GFP insert were provided by the Harvard Gene Therapy Initiative. Based on our preliminary experiments regarding optimal gene transfer conditions, freshly harvested BALB/c corneas ( $n=4$ per group) were incubated at $4^{\circ} \mathrm{C}$ or $37^{\circ} \mathrm{C}$ in a $5 \% \mathrm{CO}_{2}$ culture incubator for 2 hours with $200 \mu \mathrm{L}$ of RPMI 1640 medium (BioWhittaker, Walkersville, MD) supplemented with 10\% FBS (Hyclone, Logan, UT) containing ad-GFP. Different virus titers $\left(10^{7}\right.$ plaque-forming units [PFU], $10^{6} \mathrm{PFU}$, or no virus as the control) were tested for optimal efficacy of gene transfer. After the 2-hour incubation, the infected corneas were washed with PBS three times and immediately used as donors for corneal transplantation (Fig. 1).

\section{Orthotopic Penetrating Corneal Transplantation}

Orthotopic corneal transplantation was performed as described previously. ${ }^{7}$ Briefly, after induction of mydriasis, the recipient cornea was marked with a 2.0-mm trephine (Storz Instrument Co., St. Louis, MO) and excised with microscissors. The donor corneas infected with GFP adenoviral vector, control empty vector, or no vector were transplanted into the host corneal bed with eight interrupted 11-0 nylon sutures (Sharpoint, Vanguard, TX). The corneal sutures were removed 7 days after surgery.

\section{Localization and Assessment of GFP Gene Expression in Corneal Grafts}

BALB/c eyes $(n=4)$ bearing ad-GFP-infected corneal syngeneic grafts were enucleated and embedded in OCT on dry ice 1 week after ex vivo gene transfer and corneal transplantation. The embedded tissues were cut into $7-\mu \mathrm{m}$ cryosections and examined by epifluorescence microscopy.

The expression GFP in the corneal grafts was observed in vivo for 12 weeks by epifluorescence microscopy once daily for a week and then twice weekly after ex vivo gene transfer and corneal transplantation. At each time point, mice bearing ad-GFP-infected corneal grafts were anesthetized, and GFP expression was observed noninvasively by epifluorescence microscope. PBS was applied to the eyes to prevent corneal dryness during observation, and ophthalmic antibiotic ointment was applied afterward. The images of expressed green fluorescence in the corneal grafts were captured by digital camera (Spot; Diagnostic Instruments, Inc., Sterling Heights, MI), and the intensity and size of the GFP-expressing area within the corneal grafts in each eye was analyzed by NIH Image (available by ftp at zippy.nimh.nih. gov/ or at http://rsb.info.nih.gov/nih-image; developed by Wayne Rasband, National Institutes of Health, Bethesda, MD).
A
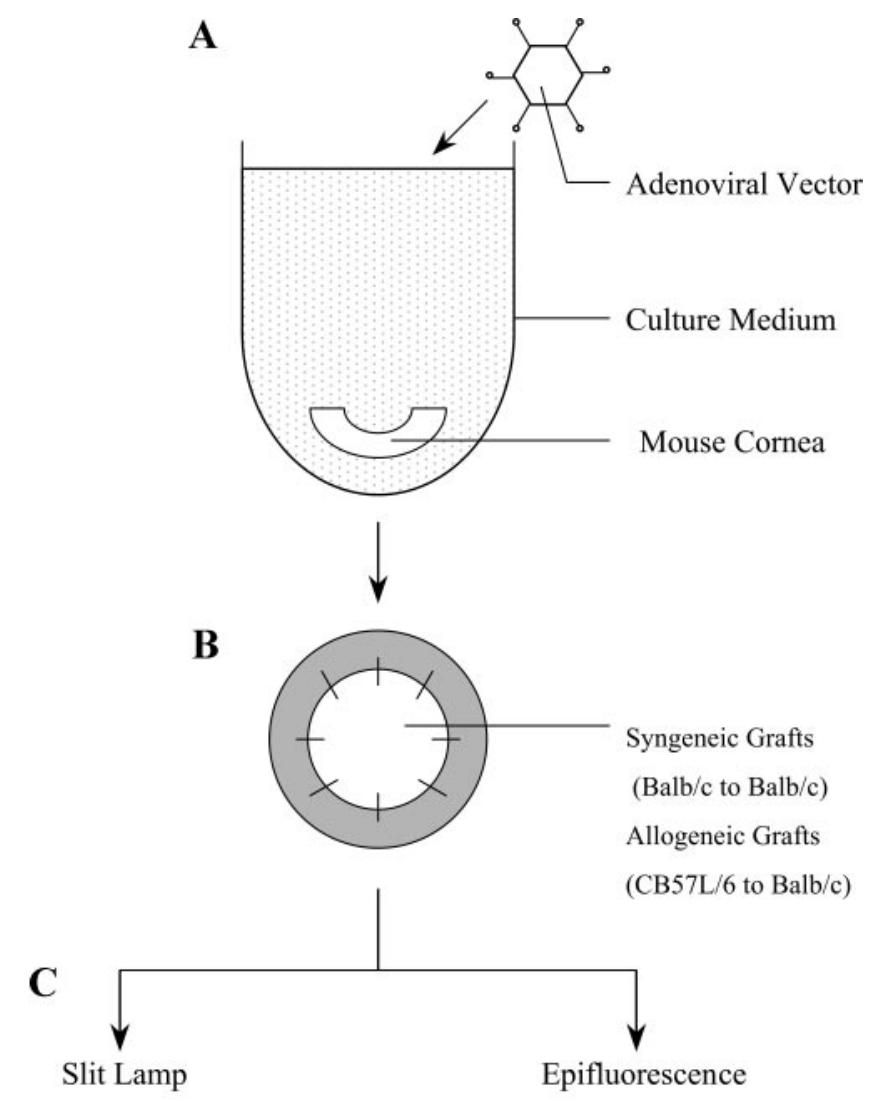

Biomicroscopy Microscopy

Figure 1. Flow diagram of experimental methods. (A) Infection of donor corneas ex vivo with adenoviral vector; (B) orthotopic penetrating corneal transplantation; (C) examination of the infected grafts by slit lamp biomicroscopy and epifluorescence microscopy.

\section{Clinical Evaluation of Corneal Grafts}

Grafts were evaluated for 12 weeks by using slit lamp biomicroscopy two times a week. At each time point, grafts were scored for opacification using a previously described and standardized scoring system that grades corneal graft opacification between 0 and $5+$. Grafts with an opacity score of $2+$ or greater after 3 weeks were considered failed. ${ }^{13}$ Kaplan-Meier analysis was used to assess the effect of transgene expression on graft survival.

\section{Results}

\section{Adenoviral Vector-Mediated GFP Gene Expression in the Endothelium of Corneal Syngeneic Grafts}

The cornea is composed of the following major layers: (1) an outer stratified squamous nonkeratinized epithelium, (2) an inner dense connective tissue stroma with its resident cells, and (3) a monolayered cuboidal endothelium bordering the anterior chamber (Fig. 2A). To evaluate whether the adenoviral vector can deliver genes to the corneal endothelium of the grafts, we examined GFP expression in cryosections of corneal grafts 1 week after ad-GFP-mediated gene transfer and corneal transplantation. GFP expression was found to be virtually entirely restricted to the corneal endothelial layer, with only trace to absent expression in the stroma (Fig. 2B). There was no GFP expression noted in the corneal epithelium. No GFP expression was seen in corneal grafts infected with empty adenoviral vector (Fig. 2C). The results indicate that adenoviral vector is 
A
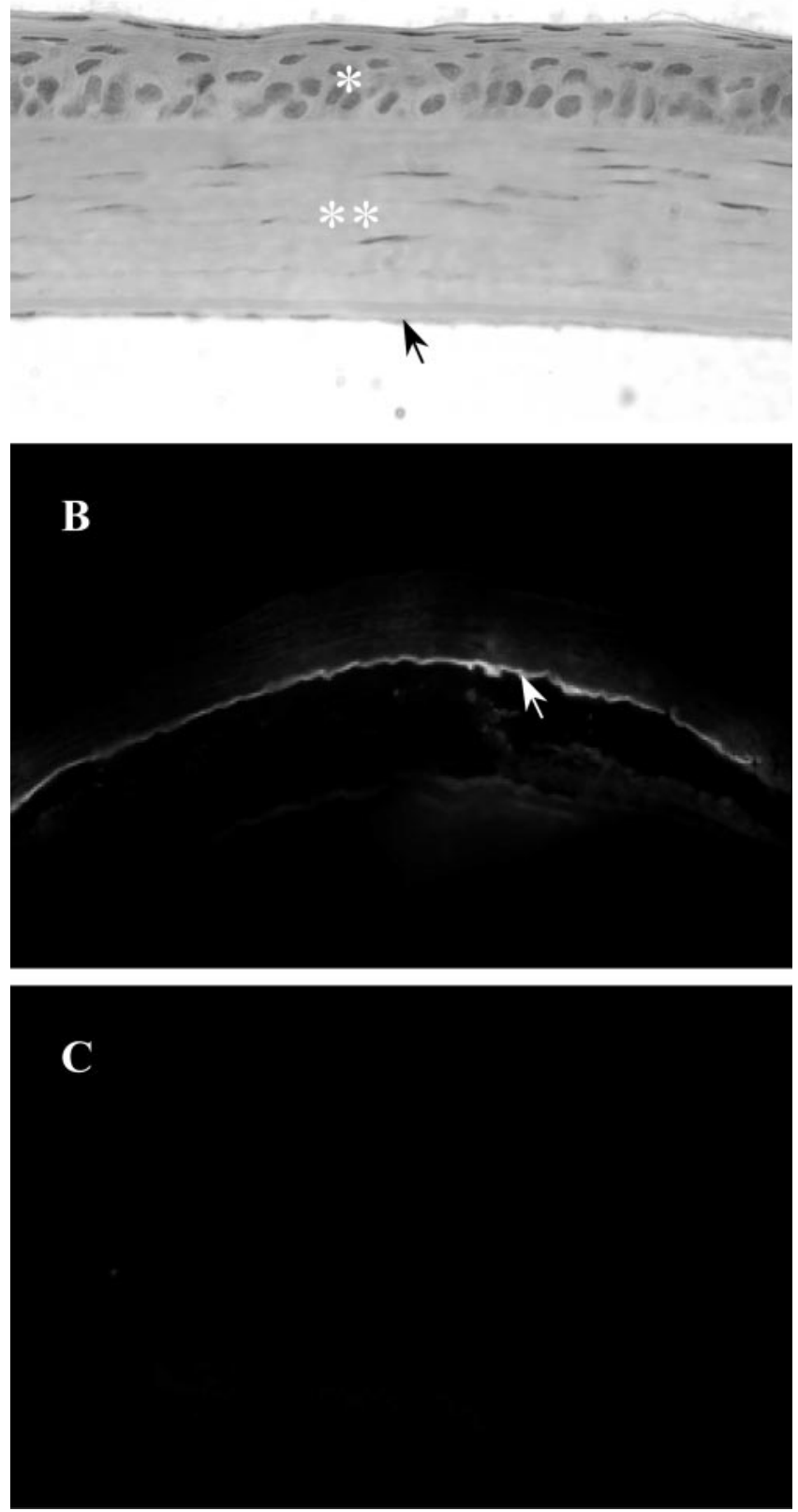

FIGURE 2. Localization of GFP in the endothelium of corneal syngeneic grafts. (A) Normal mouse cornea is histologically composed of the epithelium (*), the stroma (**), and the endothelium (arrow); (B) expression of GFP in the endothelium (arrow) of corneal syngeneic grafts; (C) no GFP expression in empty adenoviral vector-infected corneal grafts.

an efficient transfer vehicle to deliver exogenous genes specifically to corneal endothelial cells.

\section{Kinetics of GFP Expression in Adenoviral Vector-Infected Syngeneic Corneal Grafts}

To determine the lifespan of GFP in grafted corneas in the absence of alloimmunity, we used syngeneic corneal transplants (BALB/c to BALB/c mice). The BALB/c donor corneas were infected with $6 \times 10^{7} \mathrm{PFU}$ of ad-GFP for 2 hours ex vivo at either $37^{\circ} \mathrm{C}$ or $4^{\circ} \mathrm{C}$; the latter is a temperature commonly used for human donor cornea storage. With an ex vivo infection temperature of $4^{\circ} \mathrm{C}$, the syngeneic corneal grafts maintained their transparency (Fig. 3A), and in vivo expression of GFP in these syngeneic corneal grafts was demonstrated for up to 12 weeks with peak expression from day 3 to week 5 (Figs. $3 \mathrm{~B}$ and $4 \mathrm{~A})$. With an ex vivo infection temperature of $37^{\circ} \mathrm{C}$, GFP expression in the corneal grafts lasted less than 2 weeks (Fig. 4A). Syngeneic grafts incubated with the vector at $4^{\circ} \mathrm{C}$ exhibited a larger area and longer expression of green fluorescence than grafts incubated at $37^{\circ} \mathrm{C}$ (Figs. 4A, 4B). These results demonstrated that $4^{\circ} \mathrm{C}$ incubation temperature was a better infection condition to prolong GFP expression in the corneal transplants in vivo than $37^{\circ} \mathrm{C}$. Thus, under optimal infection conditions GFP gene expression could be retained in vivo, as demonstrated in syngeneic grafts, for prolonged periods.

\section{Clinical Outcome of Ad-GFP-Infected Corneal Syngeneic Grafts}

During the first week after transplantation, grafts infected with ad-GFP at $4{ }^{\circ} \mathrm{C}$ exhibited an opacity score of $2.6 \pm 0.4$ (Fig. 4C), representing a typical postoperative response seen routinely in our murine corneal transplant model, even without any viral vector infection. After removal of corneal sutures at week 1, the opacity score decreased dramatically, and the grafts became clear and maintained their transparency up to week 4 . Between weeks 4 and 8, many grafts exhibited central exposure epitheliopathy without any stromal edema, most likely due to repeated anesthesia and exposure to slit lamp biomicroscopy. In such cases the epitheliopathy spontaneously healed and left a light scar that diminished with time. Similar to the grafts infected at $4{ }^{\circ} \mathrm{C}$, grafts infected ex vivo at $37^{\circ} \mathrm{C}$ also exhibited an early postoperative opacity during the first week after transplantation. However, the opacity scores remained higher than those for $4^{\circ} \mathrm{C}$. After suture removal at week 1 , the grafts remained opaque with opacity scores ranging from $2.6 \pm$ 0.5 to $3.2 \pm 0.71$ (Fig. 4C). Thus, both in terms of GFP expression and clinical end points, the data indicate that $4^{\circ} \mathrm{C}$ incubation with viral vector is the preferred infection condition, rather than $37^{\circ} \mathrm{C}$.

\section{Adenoviral Vector-Mediated Delivery of GFP Marker Gene to Allogeneic Corneal Grafts}

Corneal allogeneic grafts infected with a high dose $\left(6 \times 10^{7}\right.$ PFU) of the viral vector at $4^{\circ} \mathrm{C}$ exhibited transient GFP expression that lasted less than a week. Considering that the cumulative effect of a higher dose of adenoviral vector in addition to allogeneic challenge of the host may be overly toxic to the corneal grafts, we reduced the vector dose to $6 \times 10^{6} \mathrm{PFU}$. Infected with this lower dose of vector, the grafts displayed continued clarity and longer GFP expression up to 3.5 weeks (Fig. 5). However, even at this lower dose, the relatively longer GFP expression afforded did not extend appreciably beyond 4 weeks - the time when graft rejection usually occurs in our murine model of corneal transplantation. ${ }^{14}$ Indeed, $100 \%$ corneal allograft infected with the adenoviral vector at the high dose of $6 \times 10^{7}$ PFU failed at week 1 , whereas the grafts infected with the adenoviral vector at a dose of $6 \times 10^{6} \mathrm{PFU}$ survived until week $3.5(P=0.0082)$. The survival rates of the grafts infected with no vector or empty vector were $50 \%$ and $25 \%$, respectively (Fig. 6), in both cases higher than in allografts infected with ad-GFP $(P<0.05)$, suggesting GFP toxicity beyond the graft damage caused by adenoviral toxicity and alloimmunity.

\section{Discussion}

Several previous studies using $L a c Z$ as a reporter gene have shown that transgene expression mediated by adenoviral vec- 

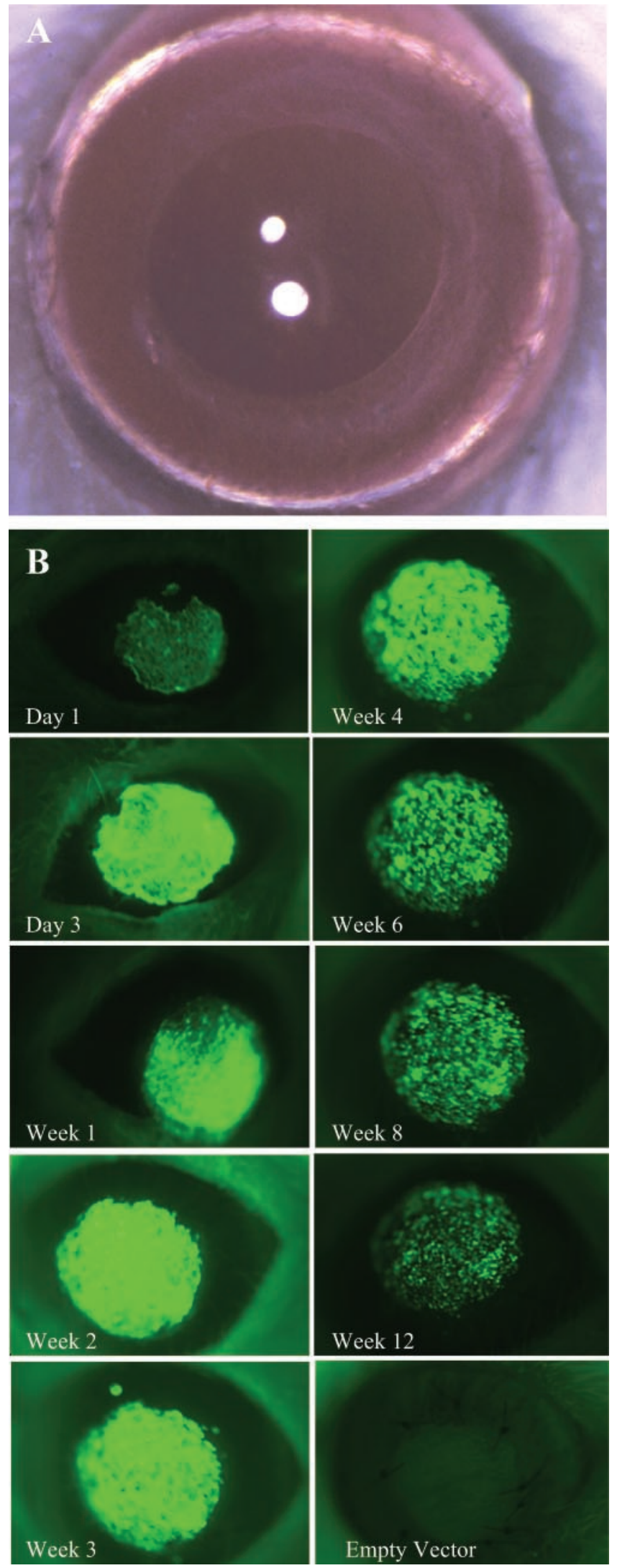

FIGURE 3. GFP expression in syngeneic corneal grafts infected with ad-GFP vector. (A) Biomicroscopic appearance of an ad-GFP infected syngeneic corneal graft at week 4; (B) GFP expression in a representative syngeneic corneal graft infected with the ad-GFP vector ex vivo at $4^{\circ} \mathrm{C}$ at different time points. tor specifically localizes to the endothelial layer of cultured corneas. $^{9-12}$ Consistent with these ex vivo studies, our results demonstrate that adenoviral vector-mediated GFP expression was confined within the endothelium of corneal grafts in vivo. However, it remains unclear why the expression of the gene product(s) was seen only in the endothelium. Wild-type adenovirus infection, as well as adenoviral vector-mediated gene transfer, depends on virus interaction with the Coxsackie adenovirus receptor (CAR), which mediates attachment of the virus to the cell surface, and on interaction with $\alpha_{\mathrm{v}} \beta_{3}$ and $\alpha_{\mathrm{v}} \beta_{5}$ integrins, which mediate virus entry into the cell. ${ }^{15,16}$ Both the epithelium and endothelium of the normal cornea express the integrin $\alpha_{\mathrm{v}} \beta_{5}{ }^{17,18}$; however, there is no report regarding the presence of CAR in the cornea in the literature. A study of the heart reveals that there is no correlation between the adeno-
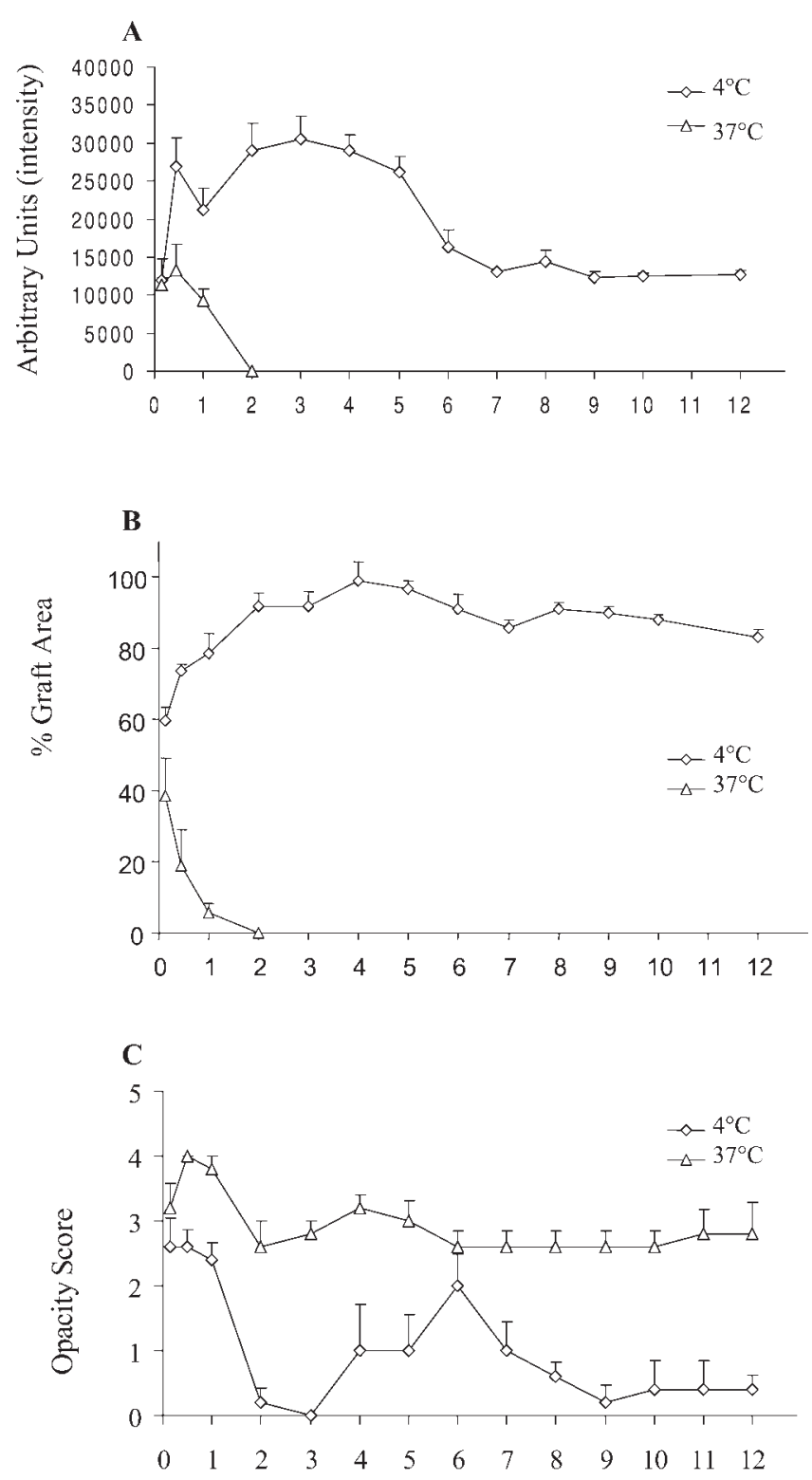

Weeks after Transplantation

FIGURE 4. Variance in GFP expression and opacity scores in corneal syngeneic grafts infected with ad-GFP vector at $4^{\circ} \mathrm{C}$ or $37^{\circ} \mathrm{C}$. (A) Kinetics (intensity) of GFP expression in ad-GFP infected grafts; (B) area of GFP expressed in ad-GFP-infected grafts; (C) opacity scores of ad-GFP-infected grafts. 

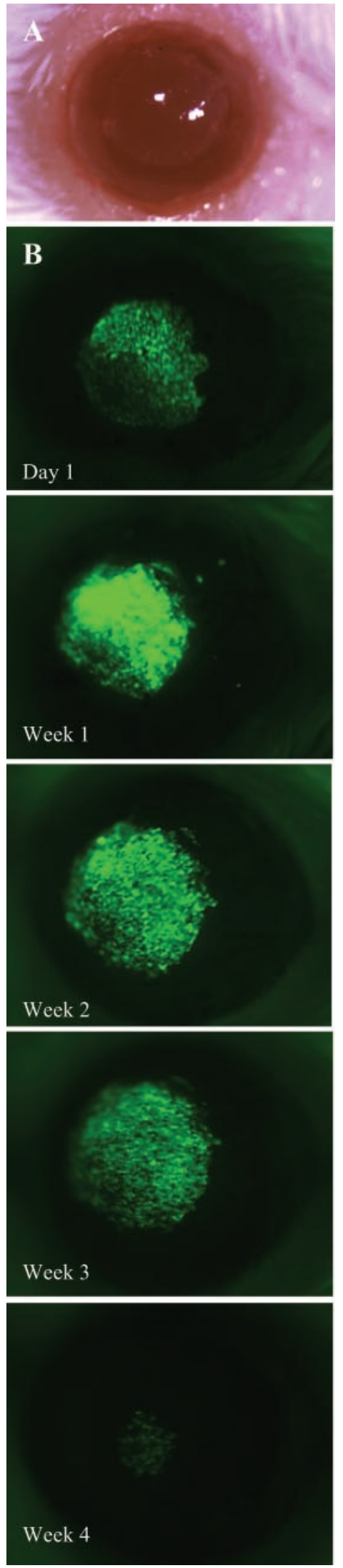

FigURE 5. GFP expression in allogeneic corneal grafts infected with ad-GFP vector at a dose of $6 \times 10^{6}$ PFU. (A) Biomicroscopic appearance of an ad-GFP-infected allogeneic corneal graft at week 1. (B) GFP expression in a representative allogeneic corneal graft infected with ad-GFP vector ex vivo at $4^{\circ} \mathrm{C}$ at different time points. viral vector expression patterns and the virus receptor patterns, ${ }^{19}$ suggesting that adenovirus receptor expression is necessary but not sufficient for vector transfer. Other factors, such as anatomic barriers ${ }^{19}$ and stages of cell cycle, ${ }^{20}$ may also play a role.

Our study is the first report regarding the fate of transgene expression mediated by adenoviral vector in corneal grafts in vivo. This is relevant because transfer of desirable genes to corneal grafts is a natural application of gene therapy strategies to the ocular anterior segment, among others. We used GFP as a marker gene, as opposed to enzyme markers such as $\beta$-gal, because GFP is readily visible with the epifluorescence microscope, ${ }^{21}$ and therefore its expression can be observed in vivo directly and prospectively without any invasive procedures, allowing correlation of gene transfer with physiological parameters of the corneal graft. We now report that prolonged and persistent adenovirus-mediated transgene expression (up to 12 weeks; last observation point) was observed in our syngeneic corneal grafts infected at $4^{\circ} \mathrm{C}$. This finding is consistent with the concept that the cornea is an immune-privileged tissue, and the anterior chamber in which the corneal endothelium is located is an immune-privileged site. ${ }^{22-24}$ Studies have shown that intracameral injection of adenoviral vector is capable of transferring exogenous genes to the corneal endothelium. ${ }^{25-27}$ However, gene transfer by this approach induces significant inflammation and certain corneal abnormalities. ${ }^{26,27}$ Moreover, delivery of vector into the anterior chamber exposes tissues other than the cornea to vector-associated gene products. In our model, the viral vector was used ex vivo, which greatly attenuated the side effects of viral infection with in vivo administration. The technology of ex vivo transgene delivery to the endothelium of syngeneic grafts may have potential clinical applications for inherited diseases of the corneal endothelium, such as Fuchs' dystrophy, in which the endothelium undergoes apoptosis with subsequent development of stromal edema. ${ }^{28}$ For example, transferring appropriate functional genes to the diseased corneas ex vivo, followed by corneal autograft transplantation, could offer one way of restoring endothelial viability and avoiding allogeneic graft rejection.

Although gene transfer was conducted at $37^{\circ} \mathrm{C}$ in all previous studies, ${ }^{9-12}$ we were more interested in infecting donor corneas at $4^{\circ} \mathrm{C}$ rather than at higher temperature, because human donor corneas are stored at $4^{\circ} \mathrm{C}$ in eye banks. Indeed, our findings demonstrate that $4^{\circ} \mathrm{C}$ is not only feasible but is superior to $37^{\circ} \mathrm{C}$ as an ex vivo infection temperature for corneas. Ex vivo GFP expression was stronger in cultured corneas infected at $37^{\circ} \mathrm{C}$ than in those infected at $4^{\circ} \mathrm{C}$ with the same dose of adenviral vector (data not shown). However, once the infected corneas were transplanted into recipients, the in vivo GFP expression in corneal grafts infected at $37^{\circ} \mathrm{C}$ became much less intense than that in those infected at $4^{\circ} \mathrm{C}$, and the grafts infected at the higher temperature before transplantation remained edematous and opaque throughout the observation period, suggesting that the function of graft endothelium became compromised at higher incubation temperatures. Corneas incubated with adenoviral vector at $4^{\circ} \mathrm{C}$ for 2 hours displayed no GFP expression ex vivo if the corneas were continuously incubated at $4^{\circ} \mathrm{C}$. However, 12 hours after transferring these corneas to $37^{\circ} \mathrm{C}$, GFP expression could be detected ex vivo (data not shown). In the aggregate, these results imply that adenoviral vector is able to attach to, or penetrate, the corneal endothelium quite effectively at $4{ }^{\circ} \mathrm{C}$, but requires higher temperatures (which would be the case once they are grafted onto a host eye) to express its encoded gene.

It is not exactly clear what explains the benefits observed with lower temperature adenoviral vector-mediated gene transfer to donor corneal tissue ex vivo. We suspect that a combination of more stable viral titers and better preservation 


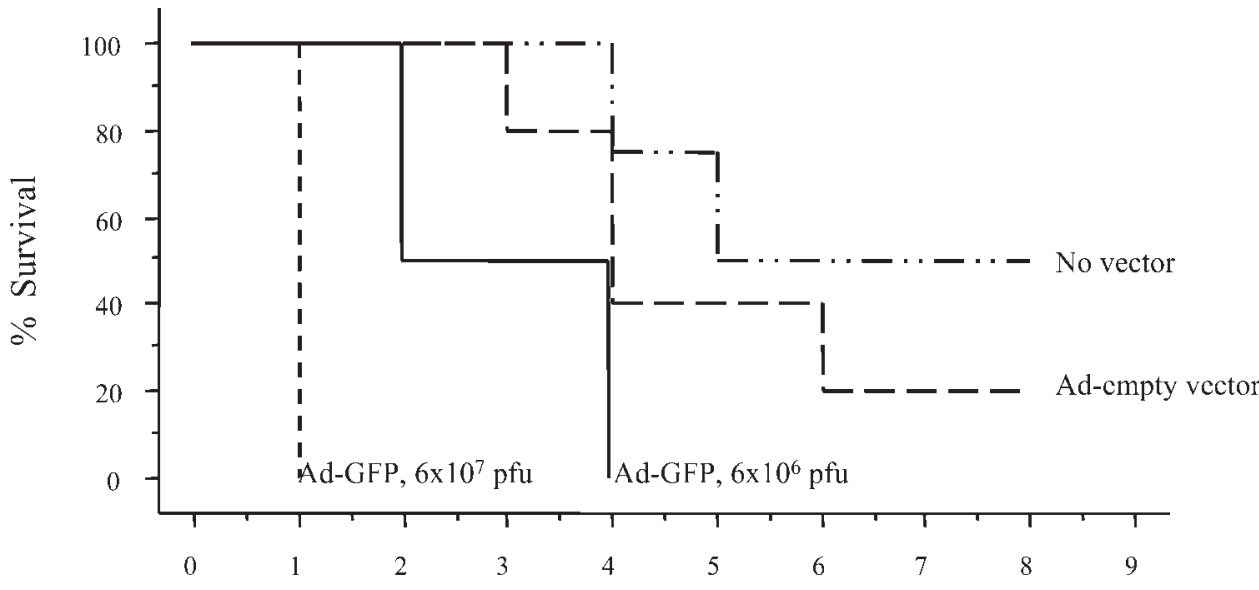

Weeks after Transplantation
Figure 6. Kaplan-Meier survival curves for allogeneic corneal grafts infected with ad-GFP vector at dose of $6 \times 10^{6} \mathrm{PFU}$ or $6 \times 10^{7} \mathrm{PFU}$. Grafts infected with empty adenoviral vector or no vector served as controls. There is a positive correlative between dose of adenoviral vector and graft failure. of corneal tissue at lower temperatures is responsible for our results. A recent study has shown that recombinant adenovirus stored at $4^{\circ} \mathrm{C}$ did not decrease its titer significantly, whereas the vector incubated at $37^{\circ} \mathrm{C}$ had marked decline in its titer over the course of 14 days. $^{29}$ It remains unclear whether a similar decrease in viral titers could occur over the 2-hour incubation period in our experiments, but this is certainly possible. Secondly, $4^{\circ} \mathrm{C}$ is the standard temperature for human corneal storage in eye banks; indeed many investigators have established that temperatures of $31^{\circ} \mathrm{C}$ or lower are appreciably better than higher temperatures (including $37^{\circ} \mathrm{C}$ ) for preserving corneal endothelial morphology and function-without which the transfection would not have been successful. ${ }^{30}$ In the aggregate therefore, we believe that the lower temperatures are far preferable for gene transfer to the corneal endothelium ex vivo.

Our findings provide relevant information for delivery of exogenous gene(s) during corneal storage of eye bank tissue similar to the effective gene transfer that has been shown during cold organ preservation for other solid organ transplants, such as liver and heart. ${ }^{31,32}$ In sharp contrast to our syngeneic data, our data show that GFP gene expression mediated by high-dose adenovirus in the setting of corneal allotransplantation is short term and toxic to grafts in vivo. Reduction in viral dose prolongs the transgene product expression and delays the onset of vector-induced graft failure. However, the desired gene expression can be retained in vivo in corneal allogeneic grafts for only short periods of time compared with that in syngeneic grafts. In addition, allografts infected with low viral doses survived for shorter periods than did empty adenoviral vector-infected allografts, and allografts infected with empty adenoviral vector showed shorter survival than did noninfected corneal allografts. These data imply that both GFP and adenoviral vector products can have deleterious side effects in the setting of allotransplantation. Indeed, the transient loss of anterior chamber-associated immune deviation (ACAID) in the allografted eyes, ${ }^{33}$ may be relevant in explaining, at least in part, the observed deleterious effects of adenoviral vector on corneal allografts. Several studies have attempted to prolong corneal allograft survival by delivering functional genes, such as TNF receptor, ${ }^{34} \mathrm{IL}-4,{ }^{35}$ and $\mathrm{IL}-10^{36}$ to donor corneas. Whereas most of these studies show minimal to no improvement in allograft survival, ${ }^{34,35}$ one study reports significant prolongation of sheep allogeneic corneal grafts infected with adeno-IL-10. ${ }^{36}$ However, the kinetics of the functional transgene expression in vivo are not reported in these studies.

In summary, our syngeneic data reflect the promise of prolonged expression of transgene products, specifically at the level of the corneal endothelium. However, based on our data derived from allogeneic grafts, caution must be exercised in interpreting the results of gene transfer strategies to corneal grafts using adenoviral vector, since it is quite possible that the real beneficial effects of the transgene product are outweighed by the deleterious effects of the adenoviral vector. The use of nonadenoviral or less immunogenic "gutless" adenoviral vectors, or indeed nonviral vectors, may be useful in circumventing some of the observed shortcomings of adenoviral vectors in the allogeneic setting. ${ }^{37}$

\section{References}

1. Smith GT, Taylor HR. Epidemiology of corneal blindness in developing countries. Refract Corneal Surg. 1991;7:436-439.

2. Bell KD, Campbell RJ, Bourne WM. Pathology of late endothelial failure: late endothelial failure of penetrating keratoplasty-study with light and electron microscopy. Cornea. 2000;19:40 - 46.

3. Pleyer U, Steuhl KP, Weidle EG, Lisch W, Thiel HJ. Corneal graft rejection: incidence, manifestation, and interaction of clinical subtypes. Transplant Proc. 1992;24:2034-2037.

4. Yang Y, Nunes FA, Berencsi K, Furth EE, Gonczol E, Wilson JM. Cellular immunity to viral antigens limits E1-deleted adenoviruses for gene therapy. Proc Natl Acad Sci USA. 1994;91:4407-4411.

5. Tripathy SK, Black HB, Goldwasser E, Leiden JM. Immune responses to transgene-encoded proteins limit the stability of gene expression after injection of replication-defective adenovirus vectors. Nat Med. 1996;2:545-550.

6. Hoffman LM, Maguire AM, Bennett J. Cell-mediated immune response and stability of intraocular transgene expression after adenovirus-mediated delivery. Invest Ophthalmol Vis Sci. 1997;38: $2224-2233$.

7. Sonoda Y, Streilein JW. Orthotopic corneal transplantation in mice-evidence that the immunogenetic rules of rejection do not apply. Transplantation. 1992;54:694-704.

8. Streilein JW. Immunobiology and immunopathology of corneal transplantation. Chem Immunol. 1999;73:186-206.

9. Oral HB, Larkin DF, Fehervari Z, et al. Ex vivo adenovirus-mediated gene transfer and immunomodulatory protein production in human cornea. Gene Ther. 1997;4:639-647.

10. Larkin DF, Oral HB, Ring CJ, Lemoine NR, George AJ. Adenovirusmediated gene delivery to the corneal endothelium. Transplantation. 1996;61:363-370.

11. Fehervari Z, Rayner SA, Oral HB, George AJ, Larkin DF. Gene transfer to ex vivo stored corneas. Cornea. 1997;16:459-464.

12. Klebe S, Sykes PJ, Coster DJ, Bloom DC, Williams KA. Gene transfer to ovine corneal endothelium. Clin Exp Ophthalmol. 2001;29:316-322.

13. Dana MR, Yamada J, Streilein JW. Topical interleukin 1 receptor antagonist promotes corneal transplant survival. Transplantation. 1997;63:1501-1507. 
14. Sonoda Y, Sano Y, Ksander B, Streilein JW. Characterization of cell-mediated immune responses elicited by orthotopic corneal allografts in mice. Invest Opbthalmol Vis Sci. 1995;36:427-434.

15. Roelvink PW, Lizonova A, Lee JG, et al. The coxsackievirus-adenovirus receptor protein can function as a cellular attachment protein for adenovirus serotypes from subgroups A, C, D, E, and F. J Virol. 1998;72:7909-7915.

16. Wickham TJ, Mathias P, Cheresh DA, Nemerow GR. Integrins alpha $\mathrm{v}$ beta 3 and alpha $\mathrm{v}$ beta 5 promote adenovirus internalization but not virus attachment. Cell. 1993;73:309-319.

17. Rayner SA, Gallop JL, George AJ, Larkin DF. Distribution of integrins alpha $\mathrm{v}$ beta 5 , alpha $\mathrm{v}$ beta 3 and alpha $\mathrm{v}$ in normal human cornea: possible implications in clinical and therapeutic adenoviral infection. Eye. 1998;12:273-277.

18. Larouche K, Leclerc S, Salesse C, Guerin SL. Expression of the alpha 5 integrin subunit gene promoter is positively regulated by the extracellular matrix component fibronectin through the transcription factor Sp1 in corneal epithelial cells in vitro. $\mathrm{J} \mathrm{Biol} \mathrm{Chem.}$ 2000;275:39182-39192.

19. Fechner H, Haack A, Wang $H$, et al. Expression of coxsackie adenovirus receptor and alphav-integrin does not correlate with adenovector targeting in vivo indicating anatomical vector barriers. Gene Ther. 1999;6:1520-1535.

20. Seidman MA, Hogan SM, Wendland RL, Worgall S, Crystal RG, Leopold PL. Variation in adenovirus receptor expression and adenovirus vector-mediated transgene expression at defined stages of the cell cycle. Mol Ther. 2001;4:13-21.

21. Chalfie M. Green fluorescent protein. Photochem Pbotobiol. 1995; 62:651-656.

22. Niederkorn JY. Immune privilege and immune regulation in the eye. Adv Immunol. 1990;48:191-226.

23. Streilein JW. Tissue barriers, immunosuppressive microenvironments, and privileged sites: the eye's point of view. Reg Immunol. 1993; 5:253-268.

24. Griffith TS, Brunner T, Fletcher SM, Green DR, Ferguson TA. Fas ligand-induced apoptosis as a mechanism of immune privilege. Science. 1995;270:1189-1192.

25. Budenz DL, Bennett J, Alonso L, Maguire A. In vivo gene transfer into murine corneal endothelial and trabecular meshwork cells. Invest Ophthalmol Vis Sci. 1995;36:2211-2215.
26. Mashhour B, Couton D, Perricaudet M, Briand P. In vivo andenovirus-mediated gene transfer into ocular tissues. Gene Ther. 1994; $1: 122-126$

27. Borras T, Gabelt BT, Klintworth GK, Peterson JC, Kaufman PL. Non-invasive observation of repeated adenoviral GFP gene delivery to the anterior segment of the monkey eye in vivo. J Gene Med. 2001;3:437-449.

28. Borderie VM, Baudrimont M, Vallee A, Ereau TL, Gray F, Laroche L. Corneal endothelial cell apoptosis in patients with Fuchs' dystrophy. Invest Opbthalmol Vis Sci. 2000;41:2501-2505.

29. Ugai H, Watanabe S, Suzuki E, Tsutsui-Nakata H, Yokoyama KK, Murata T. Stability of a recombinant adenoviral vector: optimization of conditions for storage, transport and delivery. Jpn J Cancer Res. 2002;93:598-603.

30. Sandboe FD, Medin W, Froslie KF. Influence of temperature on corneas stored in culture medium: a comparative study using functional and morphological methods. Acta Opbthalmol Scand. 2003;81:54-59.

31. Olthoff KM, Judge TA, Gelman AE, et al. Adenovirus-mediated gene transfer into cold-preserved liver allografts: survival pattern and unresponsiveness following transduction with CTLA4Ig. Nat Med. 1998;4:194-200.

32. Pellegrini C, Jeppsson A, Taner CB, et al. Highly efficient ex vivo gene transfer to the transplanted heart by means of hypothermic perfusion with a low dose of adenoviral vector. $J$ Thorac Cardiovasc Surg. 2000;119:493-500.

33. Sano Y, Okamoto S, Streilein JW. Induction of donor-specific ACAID can prolong orthotopic corneal allograft survival in "highrisk" eyes. Curr Eye Res. 1997;16:1171-1174.

34. Rayner SA, Larkin DF, George AJ. TNF receptor secretion after ex vivo adenoviral gene transfer to cornea and effect on in vivo graft survival. Invest Ophthalmol Vis Sci. 2001;42:1568-1573.

35. Pleyer U, Bertelmann E, Rieck P, Hartmann C, Volk HD, Ritter T. Survival of corneal allografts following adenovirus-mediated gene transfer of interleukin-4. Graefes Arch Clin Exp Ophthalmol. 2000;238:531-536.

36. Klebe S, Sykes PJ, Coster DJ, Krishnan R, Williams KA. Prolongation of sheep corneal allograft survival by ex vivo transfer of the gene encoding interleukin-10. Transplantation. 2001;71:12141220 .

37. Kochanek S, Schiedner G, Volpers C. High-capacity "gutless" adenoviral vectors. Curr Opin Mol Ther. 2001;3:454-463. 